\title{
Economics
}

2019; 8(3): 98-105

$\mathrm{http}: / /$ www.sciencepublishinggroup.com/j/eco

doi: $10.11648 /$ j.eco.20190803.12

ISSN: 2376-659X (Print); ISSN: 2376-6603 (Online)

\section{Analysis of the Financial Profitability of Cashew Farms in Côte d'Ivoire: Case of the Gbêkê, Hambol, Poro and Worodougou Regions}

\author{
Noufou Coulibaly ${ }^{1, *}$, Kone Siaka ${ }^{1}$, Yapi Yapo Magloire ${ }^{2}$, Toure Sally ${ }^{3}$ \\ ${ }^{1}$ Management and Applied Economics Department, Houphouët Boigny National Polytechnic Institute, Yamoussoukro, Côte d'Ivoire \\ ${ }^{2}$ Agriculture and Animal Science Department, Houphouët Boigny National Polytechnic Institute, Yamoussoukro, Côte d'Ivoire \\ ${ }^{3}$ College of Agronomy, Agro-economy Section, Houphouët Boigny National Polytechnic Institute, Yamoussoukro, Côte d'Ivoire
}

Email address:

noufou_coulibaly@yahoo.fr (N. Coulibaly),ksiakawole@gmail.com (K. Siaka), yapimagloire@yahoo.fr (Y. Y. Magloire),

sallytourets@gmail.com (T. Sally)

${ }^{*}$ Corresponding author

\section{To cite this article:}

Noufou Coulibaly, Kone Siaka, Yapi Yapo Magloire, Toure Sally. Analysis of the Financial Profitability of Cashew Farms in Côte d'Ivoire: Case of the Gbêkê, Hambol, Poro and Worodougou Regions. Economics. Vol. 8, No. 3, 2019, pp. 98-105. doi: 10.11648/j.eco.20190803.12

Received: June 17, 2019; Accepted: July 18, 2019; Published: August 10, 2019

\begin{abstract}
Low yields from cashew farms and producers' low income led the coaching organisation represented by the Cotton and Cashew Board to question the impact of the implementation of good agricultural practices (GAPs) on yields and income. The objective of this work was to study the financial profitability of cashew production in some areas in Côte d'Ivoire. To achieve this goal, we analyzed GAPs using the scores method and assessed the financial profitability of farms using the budgeting method. The study took place in the GBEKE, HAMBOL, PORO and WORODOUGOU regions of Côte d'Ivoire, and the surveys were aimed at a total sample of 160 cashew farmers. The analysis of GAPs has shown that they are implemented at $54.7 \%$. Also, their implementation has a positive impact on cashew yields because producers who strongly implement GAPs have the highest yields $(716 \mathrm{~kg} / \mathrm{ha})$. The financial profitability has revealed that the average income was $157,529 \mathrm{CFA} \mathrm{F} / \mathrm{ha}$; the average cost of production was $165 \mathrm{CFAF} / \mathrm{kg}$; and for $100 \mathrm{CFA} \mathrm{F}$ invested, the business generates 313 CFAF. Similarly, the implementation of GAPs also has a positive impact on income, because producers who strongly implement GAPs have the highest incomes, however they are the least financially profitable compared to those who implement GAPs less, because of the very high costs. Our results reflect the competing objectives of the coaching organisation that pursues farm capitalization, and of a destitute farm manager or producer who wants to maximize his profit. Productivity is a simple-looking indicator that measures the relationship between production and the factors required to achieve it. This is the primary indicator of the farmer's or farm manager's dashboard. For a destitute producer, local agricultural productivity is one of the drivers of economic growth; and the analysis of agricultural performance helps identify priorities to be defined in terms of agricultural strategies, accompanying measures, and support required. This leads them to be more rational in the use of production factors. In the light of the above, we recommend that the coaching organisations should, from this study, identify the main characteristics of cashew farms, in order to develop a base of financially profitable farms, with a view to guiding their support for cashew farmers.
\end{abstract}

Keywords: Good Agricultural Practices, Profitability, Cashew Farming, Côte d'Ivoire

\section{Introduction}

Cashew is a fruit whose almond is increasingly consumed in the world. It is produced in dry tropical ares in Africa, Asia and Latin America with an estimated world production of over 3,200,000 tonnes [1]. Three countries i.e. Côte d'Ivoire,
India and Vietnam account for more than half of the production, with more than $1,675,000$ tonnes, or $54 \%$. Cote d'Ivoire, the world's largest cashew producer since 2015, started to focus on this crop in the 1970s. However, it was only from 1990 to 2000 that cashew actually boomed. Indeed, at that time, the Indian market had opened, leading to an 
increased price of nuts in the international market. The Ivorian Government took advantage of the situation to set up the Cotton and Cashew Regulatory Authority (ARECA) in 2003, which aimed to better organize the sector, as surfaces were increasing with greater production. However, between 2003 and 2012, the Ivorian Government noted poor organization of producers in the sector, and low yields. Yields were estimated at $250 \mathrm{~kg} / \mathrm{ha}$ whilst India or Vietnam produced up to 2 tonnes per hectare [2]. Nonetheless, with high hopes for the sector, the Ivorian Government decided in 2013 to reform it and address its shortcomings. The reform led to the creation of a new organisation, the Cotton and Cashew Board (Conseil du Coton et de l'Anacarde or CCA), which aims to improve the governance of value chains and productivity and ensure better remuneration for producers. To this end, it implemented several strategies, including a research program to improve seedlings, and a Cashew Agricultural Board (Conseil Agricole Anacarde) to promote the dissemination of Good Agricultural Practices (GAPs). The main purpose of GAPs is to improve yields. Despite these efforts, yields are still low (300-500 kg/ha) and producer incomes are low. On the basis of these observations, a question arises: Does the implementation of good agricultural practices have any positive impact on producer's yieds and incomes?

The overall objective of our study was to make a financial analysis of cashew farms in the GBEKE, HAMBOL, PORO and WORODOUGOU areas. Specifically, this involved analysing good agricultural practices and the financial viability of cashew farms.

\section{Literature Review}

\subsection{Good Agricultural Practices}

Good Agricultural Practices is a phrase used by various organizations related to agriculture. This term refers to a set of rules to be respected (good practice) in establishing and developing crops in order to optimize agricultural production, while reducing as much as possible the risks associated with such practices, both vis-à-vis humans and the environment. For the FAO, good agricultural practices are based on 11 guiding principles. As a result, they apply not only to a given farm's entire production and value chain of a plant or animal product, but also to the various sub-components of agriculture. Several studies have been undertaken to analyze GAPs [3].

Chiapo researched the determinants of adoption of good agricultural practices by cashew farmers in Côte d'Ivoire. He used the scores method to measure the level of appreciation or implementation of good practices. He combined with this tool an econometric model to estimate the adoption determinants, namely the double truncation TOBIT model. The results obtained showed that good agricultural practices were adopted by Ivorian cashew producers but at different levels of intensity [3].

Ouattara, in investigating the determinants of the adoption of some good pre-harvest cropping practices for cashew nuts in Côte d'Ivoire, used an unordered multinomial LOGIT as an econometric model. The results show that location and education level foster the adoption of some good practices before harvest, unlike farmer age and household size [4].

\subsection{Financial Profitability}

Financial profitability expresses the financial income (profit, interest) of an agent. In other words, financial profitability is the ratio between the net profit and the asset. It makes it possible to assess the profit derived from the mobilization of the farmer's equity [5]. In practice, the techniques generally used to evaluate the financial profitability of agricultural activities are: budgeting and the approach based on the estimation of a production function [5]. However, it is the cost estimation method that is the focus of our work. This can be achieved by calculating several indicators.

\subsubsection{Farming Income (FI)}

According to Eddy, it represents what the farm leaves to the producer for his work, his land and his management. It is the result from the difference between the gross product in value $(\mathrm{GP})^{1}$ and the actual costs (AC) consisting of fixed costs $(\mathrm{CF})$ and average variable costs (VC).

The farming income is therefore: FI $(\mathrm{CFA} \mathrm{F})=\mathrm{GP}-\mathrm{AC}=$ $\mathrm{GP}$ - (VC + FC). If the farming income is positive, then it can be concluded that the activity is economically profitable. However, if the result is negative, then the activity is said to be not economically profitable. This happens when the total costs are too high and the gross product is too low to cover them. According to Paraïso et al, very high fixed costs may make the farming income negative in the case of large investments [6]. This indicator is also used to measure business performance, which will be called value added [7].

\subsubsection{Cost of Production (CP)}

This is the expression in value, usually in monetary terms, of the use of production factors that have been used during a given period in a given institution to obtain certain products.

It is measured by the ratio: $\mathrm{CP}(\mathrm{ha})=(\mathrm{VC}+\mathrm{FC}+\mathrm{FL}) /$ No. ha for the production cost per ha; $\mathrm{CP}(\mathrm{kg})=(\mathrm{VC}+\mathrm{FC}+\mathrm{FL})$ / Product for the cost of production per $\mathrm{Kg}$.

Where: $\mathrm{CP}(\mathrm{Kg})=$ Production cost per kilo of cashew; $\mathrm{CP}$ (ha) $=$ cost of production per ha; $\mathrm{FC}=$ fixed costs; $\mathrm{VC}=$ variable costs; $\mathrm{FL}=$ family labor in value; $\mathrm{GP}=$ gross product in value; No. ha: Number of hectares. Caroline K. P. Séhouéto and al, as part of a study of the production of tech plant, used this indicator [8].

The cost of production per kilogram is compared to the selling price of the product on the market. It determines the commercial margin - the commercial margin being the difference between the cost of production (CP) and the selling price $(\mathrm{PV})$ of the product. If $\mathrm{CP}<\mathrm{PV}$, then it is

1 The gross product (GP) represents the value of all final productions during an accounting period; it includes the amount of sales, the value of consumed production, and any inventory variations. 
worthwile to produce it. If not, it is not worthwhile to produce it [5]. The cost of production per hectare expresses the amount invested per hectare. It is compared to gross income per hectare. If it is greater than the income per hectare, then the activity is not economically profitable. In the opposite case, it is worthwile to carry out the activity.

\subsubsection{Cost-Benefit Ratio (R)}

The cost-benefit ratio expresses the total financial gain obtained by investing a monetary unit (1 CFA F for example). If we consider $\mathrm{B}$ as the aggregate of profits obtained with a total investment $\mathrm{I}$, and $\mathrm{R}$ the financial profitability indicator, according to Darbelet, Laugine, quoted by Eddy [5], we have: $\mathrm{R}=\mathrm{B} / \mathrm{I}$. In agricultural economics, $\mathrm{B}$ is designated by the gross agricultural product obtained in value (GP), and I, the investment, in other words, all of the costs expressed in value, including family labor $(\mathrm{I}=\mathrm{FC}+\mathrm{VC}+\mathrm{FL}=\mathrm{TC})$. Thus, if GP is the gross product in value, and if $\mathrm{TC}$ is the total costs comprising the value of fixed costs (FC), of variable costs (VC) and the total value of family labor used (FL), then $\mathrm{R}=$ $\mathrm{B} / \mathrm{I}=\mathrm{GP} /(\mathrm{FC}+\mathrm{VC}+\mathrm{FL})=\mathrm{GP} / \mathrm{ATC}$.

Where: I is the investment, or the total cost; CTM is the Average total cost.

In economic profitability analysis, if $\mathrm{GP} / \mathrm{TC}>1$, this means that an invested $1 \mathrm{CFAF}$ generates more than $1 \mathrm{CFA} \mathrm{F}$ as a profit, and the activity is said to be financially profitable. However, if GP/TC $<1$, then an invested 1 CFA F generates less than 1 CFA F as profit, and the activity is said to be not financially profitable. The producer then earns less than he invests.

In this connection, several authors have used the budgeting method:

Agba and Odoun-Ifa have developed producer operating accounts and calculated the rate of return to analyze the economic profitability of cotton production in Benin [9]. Indeed, taking into account all the elements of the cost structure, cotton production is profitable overall as it produces a positive net result. Paraïso et al., used gross profit, gross income, net production margin, net income, internal rate of return and the profit-cost ratio for the profitability analysis of fonio production in Benin The results showed that fonio was profitable in the various regions surveyed [10].

Assiri et al used the calculation of the average annual yield and the average rate of return to analyze the economic profitability of the rehabilitation and replanting techniques of old cocoa orchards in Côte d'Ivoire [11]. He showed that the rehabilitation of adult plantations based on adequate maintenance and integrated pest management leads to increased production by 20 to $221 \%$, with an average rate of return of up to $377 \%$ compared to the control farms.

Ayena and Yabi referred to net margin $(\mathrm{GN})$, average labor productivity (PML) and internal rate of return (IRR) calculations to show that cotton producers are economically profitable [12]. Indeed, these indicators were all positive and statistically equal to the $5 \%$ threshold.

Eddy analyzed the profitability of cashew farms in Côte d'Ivoire using indicators such as farming income, cost of production, and per working day remuneration for the economic part, and cost-benefit ratio for financial profitability. These indicators showned that cashew is economically and financially profitable in all production regions except the Belier region [5].

Somé in his socio-economic analysis of cashew production systems in Burkina Faso found that the average area farmed was 7.7 ha with an average yield of 283.51 $\mathrm{kg} / \mathrm{ha}$. The average cost of maintaining orchards is 4,008 $\mathrm{CFAF} / \mathrm{ha}$ and 5,512 CFAF/ha respectively for input costs and wage bill. Comparatively, the Cascades region produced better than the Hauts-Bassins, with a profit margin of 42,968 CFAF/ha against 39,978 CFAF/ha [13]. In the use of Cost-Benefit Ratio and budgeting method, we can also mention the studies of Asala and Ebukiba [14], Silue et al [16], Hafdhi [15], respectively on the profitability of yam production systems in Nigeria and Burkina Faso, and on the profitability comparison of a cooperative and a private enterprise.

\section{Methodology}

\subsection{Study Area and Sampling}

The data in our study are from the 2017-2018 seaon. They were collected in North-Western and Central Côte d'Ivoire. The Gbêkê, Hambol, Poro and Worodougou regions were chosen based on their production (high or medium) during the 2016-2017 season, but also because of their accessibility. The villages were chosen on the recommendation of the assistants to regional delegates depending on the cities in which they have relay agents. Regarding producers, the sample involves all those who own cashew farms in the regions concerned. The study sample consists of 40 producers per administrative region. Our respondents were randomly selected from the cashew farmer population while taking into account availability, accessibility, farm production, and willingness to answer questions. The data were collected using a previously established questionnaire. The information involved was related to farmer description, farmer training and information, and the characteristics and costs of his farm. The data was collected in the field with the help of relay agents from the Cotton and Cashew Board. The method of administration of the questionnaire to producers is the direct or face-to-face method.

\subsection{Tools and Method}

\subsubsection{Analysis of the Implementation of Good Agricultural Practices}

Analysis of the Implementation of Good Agricultural Practices

The analysis of agricultural practices was performed through descriptive statistics followed by a classification by level of implementation of GAPs. Table 1 presents the selected variables.

The classification method used for GAPs is the scores method. It is done according to the level of implementation 
of GAPs:

We start by assigning a coefficient $(1=$ yes, $0=$ no $)$ of implementation to each GAP because we expect an impact on the one who applies the GAPs.

Then, we calculate the average score obtained by each producer based on the formula: Average Score $=\frac{\sum \text { score } i}{N}$ where $\mathrm{N}$ is the number of practices considered.

Thereafter, we calculate a producer implementation rate, based on the following formula:

$$
\text { ProdRate }=\frac{\sum_{i}^{n} \text { score } i}{\text { maximum total score }}
$$

And we calculate the average rate (AvRate) and the deviation for the rates obtained.

At the end of these stages, producers are ranked according to the rate obtained based on the following criterion:

Weak implementation: ProdRate $\leq$ (AvRate - Standard deviation).

Average implementation: (AvRate - Standard deviation) $\leq$ ProdRate $<$ AvRate.

Strong implementation: ProdRate $\geq$ AvRate.

The classification of farms is done throughout the study area. It is based on the intensity of GAP adoption. In this section, practices related to the creation (picketing and holing, planting, shape pruning), to post-harvest (fruit picking separation by string method, drying, sorting, packaging with jute bags, storage) as well as overgrafting and coppicing were not considered. It is assumed that for the first group, it has no impact on production as the orchards are already mature (mean age $=27$ years). For the second group, it is more related to the quality of nuts. As for overgrafting, coppicing and the use of fertilizers, these practices are almost unimplemented, so they are of little significance in the context of this analysis.

Our analysis did not include the following practices: cleaning, fire guard, pruning, thinning, insecticide and herbicide use. The choice of these practices is partly justified by the results of the works by OUATTARA [4]. These proved that among the pre-harvest practices, weeding (clearing in our case), pest control (use of insecticide in our case) and pruning are the most practiced respectively at $15.45 \%, 79.25 \%$ and $2.65 \%$. He also justified the rate of the last practice by producer's poor knowledge of it.

\subsubsection{Financial Profitability}

We analyse financial profitability using the budgeting method because it helps take into account several tools. This method amounts to calculating profitability indicators. The analysis of financial profitability was done at two levels, depending on the regions and on classes obtained. The variables selected for the analysis of financial profitability are:

$$
\text { Farming Income (FI) in CFA F: FI }=\mathrm{GP}-\mathrm{AC}=
$$

$$
\mathrm{GP}-(\mathrm{VC}+\mathrm{FC})
$$

Cost of Production (CP) in CFA F:

$$
\begin{gathered}
\mathrm{CP}(\mathrm{ha})=(\mathrm{VC}+\mathrm{FC}+\mathrm{FL}) / \text { Nbre ha } \\
\mathrm{CP}(\mathrm{kg})=(\mathrm{VC}+\mathrm{FC}+\mathrm{FL}) / \mathrm{GP}(\mathrm{kg}) \\
\text { Cost }- \text { Benefit Ratio (R): R }=\mathrm{B} / \mathrm{I}=\mathrm{GP} /(\mathrm{FC}+\mathrm{VC}+ \\
\mathrm{FL})=\mathrm{GP} / \mathrm{TC}
\end{gathered}
$$

With FI: farming Income; AC: Actual Costs; CP (kg): Production cost per kilo of cashew; CP (ha): cost of production per ha; FC: average fixed costs; VC: average variable costs; FL: average family labor in value; GP: average gross product in value; No. ha: Number of hectares.

\section{Results and Discussions}

\subsection{Characterization of Farms}

The results show that cashew farms are 27 years old on average (Table 1), and indicate that the orchard is mature. Most of them stem from seedlings, with a spacing of less than $10 \mathrm{~m}$ between plants. The farms are mostly pure (55 to $70 \%$ ) with an average area of 5.3 ha but often there are associated crops such as maize, peanuts, rice, cassava, and

\begin{tabular}{|c|c|c|c|c|c|}
\hline \multirow{2}{*}{ Characteristics of farms } & \multicolumn{4}{|l|}{ REGIONS } & \multirow{2}{*}{ THE 4 ZONES } \\
\hline & GBEKE & HAMBOL & PORO & WORODOUGOU & \\
\hline Cashew farm area & 3.42 & 5.87 & 5.79 & 6.28 & 5.34 \\
\hline Farm age & 23 & 27 & 27 & 31 & 27 \\
\hline Farming method & Seeding $(88 \%)$ & Seeding $(95 \%)$ & Seeding $(95 \%)$ & Seeding $(100 \%)$ & Seeding (94\%) \\
\hline Type of plantation & Pure $(70 \%)$ & Pure $(73 \%)$ & Pure $(55 \%)$ & Pure $(65 \%)$ & Pure $(66 \%)$ \\
\hline Spacing between plants & Less than $10 \mathrm{~m}(75 \%)$ & Less than $10 \mathrm{~m}(88 \%)$ & Less than $10 \mathrm{~m}(70 \%)$ & Less than $10 \mathrm{~m}(63 \%)$ & Less than $10 \mathrm{~m}(74 \%)$ \\
\hline Average yield & 471 & 304 & 344 & 327 & 361 \\
\hline
\end{tabular}
yam. These farms represent the main activity for $80 \%$ of producers. The yield is $361 \mathrm{~kg} / \mathrm{ha}$ on average in the study areas, which represents $18 \%$ of the potential of the cashew tree. The Gbêkê region is doing slightly better with around $24 \%$ of potential.

Table 1. Characteristics of cashew farms.

Cashew farmers are $89 \%$ male and 48 years old on average, and $89 \%$ of them live in a couple (Table 2). Most of them accessed land by inheritance and tend to have 15 dependents on average. In addition, they have an average experience of
16 years. Only $48 \%$ belong to a peasant organization. Also, $52 \%$ are uneducated. $28 \%$ have received technical support through the ANADER (National rural development agency). 
Table 2. Characteristics of Cashew Producers.

\begin{tabular}{|c|c|c|c|c|c|}
\hline \multirow{2}{*}{ Characteristics of producers } & \multicolumn{4}{|l|}{ REGIONS } & \multirow{2}{*}{ THE 4 ZONES } \\
\hline & GBEKE & HAMBOL & PORO & WORODOUGOU & \\
\hline Producer's gender & Male $(75 \%)$ & Male $(87.5 \%)$ & Male $(92.5 \%)$ & Male $(100 \%)$ & Male $(88.75 \%)$ \\
\hline Producer's age & 46 & 46 & 51 & 48 & 48 \\
\hline Years of experience & 16.23 & 17.63 & 14.60 & 13.90 & 15.59 \\
\hline Marital status & Cohabitation $(60 \%)$ & Cohabitation $(65 \%)$ & Married (92.5\%) & Married (60\%) & Couple (89\%) \\
\hline Number of dependants & 16 & 18 & 15 & 14 & 16 \\
\hline Membership of a peasant organisation & No $(60 \%)$ & No $(60 \%)$ & Yes $(57.5 \%)$ & Yes $(55 \%)$ & No $(51.875 \%)$ \\
\hline Level of education & $\begin{array}{l}\text { Out of school } \\
(55 \%)\end{array}$ & Primary $(47.5 \%)$ & $\begin{array}{l}\text { Out of school } \\
(60 \%)\end{array}$ & $\begin{array}{l}\text { Out of school } \\
(60 \%)\end{array}$ & $\begin{array}{l}\text { Out of school } \\
(51.875 \%)\end{array}$ \\
\hline Agricultural advisory service in 2018 & No $(83 \%)$ & No $(75 \%)$ & No $(58 \%)$ & No $(70 \%)$ & No $(71 \%)$ \\
\hline Land acquisition method & Inheritance ( $80 \%)$ & Inheritance $(70 \%)$ & Inheritance (95\%) & Inheritance $(75 \%)$ & Inheritance $(80 \%)$ \\
\hline Use of fertilisers & $3 \%$ & $5 \%$ & $3 \%$ & $10 \%$ & $5 \%$ \\
\hline
\end{tabular}

\subsection{Analysis of Good Agricultural Practices}

In the 4 regions (Figure 1), $54.7 \%$ of good agricultural practices are adopted by farmers. The most marginalized practices are picketing and holing (38\%), planting (8\%), coppicing (11\%) and overgrafting (1\%). This can be explained by the fact that the recommendations for these practices are only recent (less than 5 years old) whereas the farms are already mature. These practices are most often for new farms, making it difficult for growers to implement them Also, if they are not yet convinced of their usefulness, they will continue to abandon them. Severing cashews using the string method $(17 \%)$ is not the preferred practice of producers. Similarly, the PSAC study found a completion rate of $1.9 \%$ [17]. Producers find it slow and expensive because the strings used are not resistant, and they have to buy several rolls for the entire farm. It is also noted that the most used phytosanitary products are herbicides $(81 \%)$ which reduce the manual work of producers in general compared to insecticides $(31 \%)$. Also, the thinning rate $(69 \%)$ is quite high. This is because the Cotton and Cashew Board emphasises this aspect during training and awareness. Indeed, while producers thought production was essentially proportional to the number of plants per hectare, they were informed that maintenance was a factor of better productivity. Those who have very dense farms are starting to cut off the excess plants until they reach the $10 \mathrm{~m}$ spacing between plants. Shape pruning is restricted to seedlings up to 2 years old. It is also very little used (49\%) by producers because it is intended for young plants. Since the farms are very old, this percentage seems reasonable.

In the 4 regions

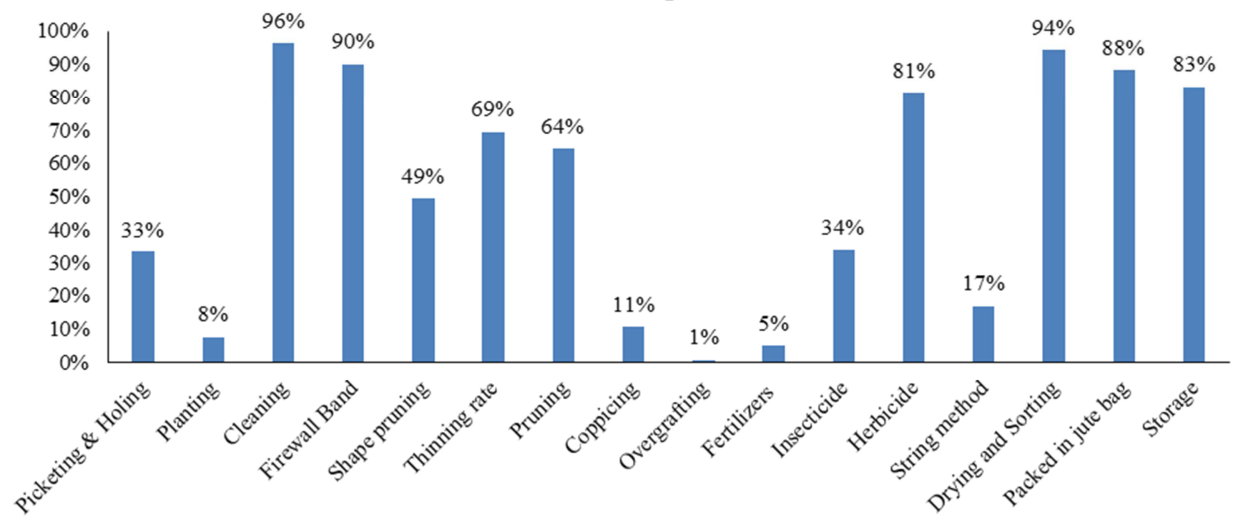

Figure 1. Good Agricultural Practices over the entire study area.

\subsection{Classification of Good Agricultural Practices}

The environment of our sample shows that producers implement at least one of the selected GAPs (Table 3).

Table 3. Classification based on GAPs.

\begin{tabular}{|c|c|c|c|c|c|c|c|c|c|c|}
\hline Classes & $\begin{array}{l}\text { Implementation } \\
\text { of GAPs }\end{array}$ & $\begin{array}{l}\text { Total } \\
\text { staffing }\end{array}$ & $\begin{array}{l}\text { Average } \\
\text { yield }\end{array}$ & Area (ha) & Clearing & $\begin{array}{l}\text { Fire } \\
\text { guard }\end{array}$ & Thinning & Pruning & Insecticide & Herbicide \\
\hline Class 1 & Weak & 35 & 396 & 7 & 34 & 25 & 8 & 3 & 3 & 24 \\
\hline Class 2 & Average & 96 & 426 & 5 & 29 & 90 & 74 & 71 & 22 & 76 \\
\hline Class 3 & Strong & 29 & 716 & 4 & 91 & 29 & 29 & 29 & 29 & 29 \\
\hline Grand Total & & 160 & 472 & 5 & 154 & 144 & 111 & 103 & 54 & 129 \\
\hline
\end{tabular}


The analysis of these three classes shows a positive correlation between yields and the implementation of GAPs. In fact, those who implement GAPs poorly have the lowest average yield (396 kg/ha). The same reasoning applies to those who implement them moderately (426 kg/ha) and strongly $(716 \mathrm{~kg} / \mathrm{ha})$. It is inferred that the implementation of GAPs (clearing, fire guard, thinning, pruning, insecticide and herbicide use) has a positive impact on yields. This inferrence is verified by the PEARSON correlation test. A negative correlation between the yields and the area, verified by the PEARSON correlation test is noted. In fact, owners of small areas (4 ha) have a better yield $(716 \mathrm{~kg} / \mathrm{ha})$ than those with large areas.
In the same vein, SOME found that the average area of 7.7 ha has an average yield of $283.51 \mathrm{~kg} / \mathrm{ha}$ [11]. Similarly, Youan Bi found that those with an average area of 3.07 ha have an average yield of $742.60 \mathrm{~kg} / \mathrm{ha}$ [18]. This finding highlights the law of diminishing marginal returns. In other words, in our case, when we exceed an area of 4 ha, the yield per hectare decreases. This can also be justified by the fact that, over large areas, producers have difficulty implementing GAPs. Farm size is therefore a limiting factor in the implementation of GAPs. This is supported by CHIAPO, who showed that on a scale of 0 to 3 , the "Farm Size" constraint scored 1.38 in the ranking of the constraints related to GAP implementation [3].

\begin{tabular}{|c|c|c|c|c|c|c|c|}
\hline Variable & Obs. & Obs. with missing data & $\begin{array}{c}\text { Obs. without missing } \\
\text { data }\end{array}$ & Minimum & $\underset{\mathrm{m}}{\operatorname{Maximu}}$ & Average & $\begin{array}{l}\text { Standard } \\
\text { deviation }\end{array}$ \\
\hline sup_anacarde & 16 & 0 & 160 & 0,500 & 32,000 & 5,338 & 5,478 \\
\hline Rendement & 16 & 0 & 160 & 25,000 & 2400,000 & 471,729 & 352,903 \\
\hline
\end{tabular}

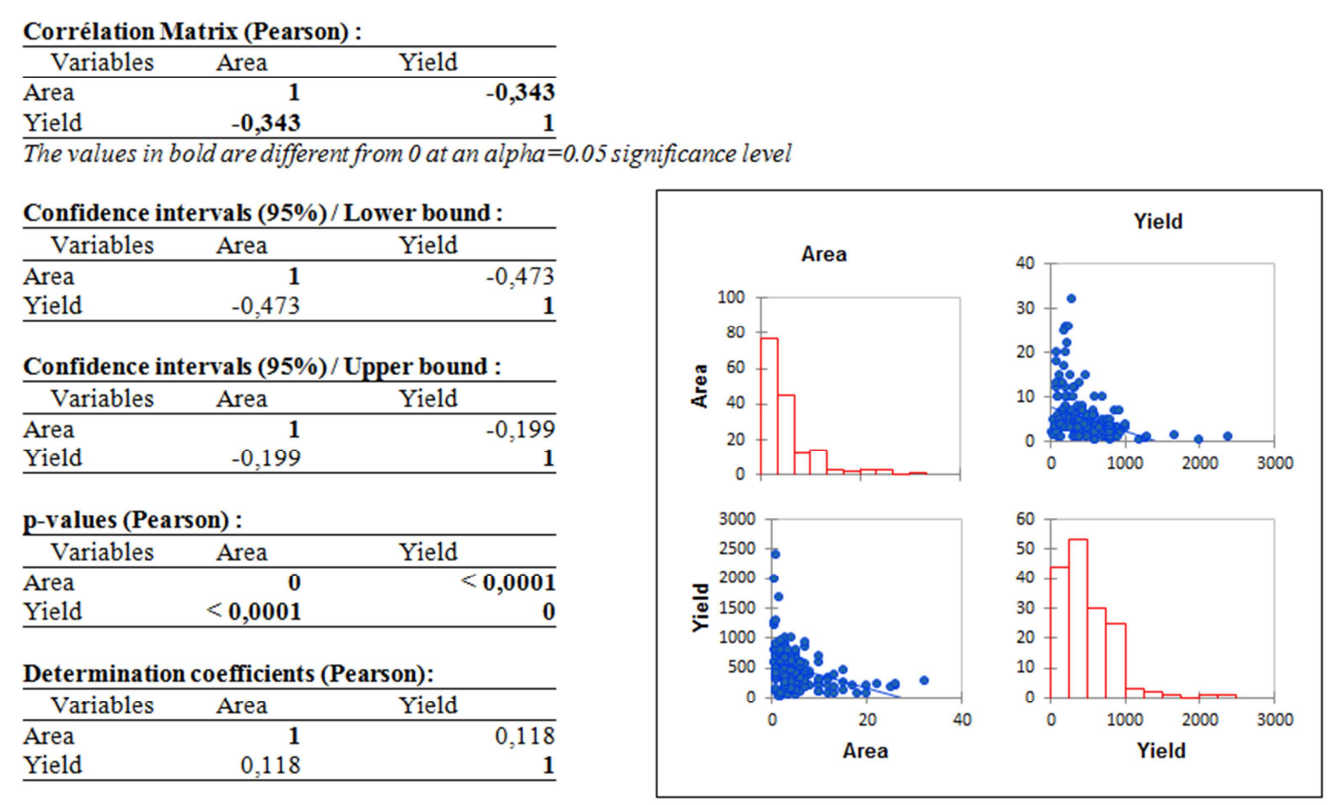

Figure 2. Pearson's area and yield correlation test.

After analyzing the correlation that may exist between farm area and yield, the following section analyzed the financial profitability by area and by class. The results allowed us to verify the impact of GAP implementation on financial profitability.

\subsection{Analysis of Financial Profitability}

\subsubsection{Zonal Financial Profitability}

\section{i. Farming Income (FI)}

The analysis shows that cashew generates a farming income per hectare ranging between 111,693 CFA F and 177,304 CFA $F$ across regions with an average of 157,529 CFAF. Over the entire study area, the results obtained can be explained by the fact that the average price used - the floor price for the 2017-2018 season - is the same for all regions
(500 CFA F, Equivalent to 1 US \$). In addition, these results take into account costs such as fertilizers, insecticides and herbicides. For a workload of $253 \mathrm{md} / \mathrm{ha}$, a working day is estimated at about $625 \mathrm{CFA} \mathrm{F}$, which is lower than a salaried worker's daily remuneration estimated at 1,200 CFA F. To bypass this, the producer very often uses family labor, which is limited because children are increasingly schooling or attracted to non-agricultural activities. To support himself, the producer is obliged to grow food crops or engage in other non-agricultural activities. These results demonstrate the low profitability of cashew farming.

ii. Cost of Production (CP)

The cost of production by region is calculated taking into account family labor, and without considering family labour. The cost of production per hectare taking into account family 
labor varies from 120,852 CFAF to 300,315 CFA F with an average of 209923 CFA F. This cost of production per kilogram varies from $278 \mathrm{CFA} \mathrm{F}$ to $532 \mathrm{CFAF}$ with an average of $430 \mathrm{CFAF}$. The commercial margin per kilogram ranges from $-38 \mathrm{CFAF}$ and $222 \mathrm{CFA} F$ with an average of 70 CFA F. The cost of production per hectare without taking into account family labour ranges from 51,951 CFA francs to 106,120 CFA francs with an average of 78,335 CFA francs. This cost of production per kilogram varies from $120 \mathrm{CFAF}$ to $188 \mathrm{CFAF}$ with an average of $165 \mathrm{CFAF}$. The commercial margin per kilogram ranges from 312 CFAF to 380 CFA with an average of 335 CFAF.

\section{iii. Cost-Benefit Ratio (R)}

Where labour is taken into account, the cost-benefit ratio ranges from 0.93 to 1.80 with an average of 1.25 for the 4 regions. It is higher than 1 in the WORODOUGOU and HAMBOL regions. Where labour is not considered, the cost-benefit ratio ranges from 2.66 to 4.18 with an average of 3.13 for the 4 regions. It is greater than 1 in all regions; however, it is preferable to produce in the WORODOUGOU from the ratio point of view. On average, for $100 \mathrm{CFAF}$ invested, producers earn $313 \mathrm{CFAF}$. Cashew is therefore financially profitable overall.

\subsubsection{Financial Profitability by Class}

i. Farming Income (FI) by Class

The farming income of producers who implement GAPs poorly is 148,903 CFAF. It is 135,113 CFAF for those who implement them averagely, and 244,042 CFAF for those who implement them strongly. The last class have the highest farming income. It can be inferred that strong implementation of GAPs leads to increased farming income. Therefore, implementing GAPs has a positive impact on income.

\section{ii. Cost of Production (CP) by Class}

The results show that those who implement GAPs poorly have a lower cost of production and a higher margin than those who implement them strongly. The latter have the highest cost of production and the lowest margins. These results can be explained by the fact that they incur higher costs because they use all phytosanitary products for maintenance and implement all GAPs and have different yields depending on classes. However, the margin difference is not high (33 CFA F).

\section{iii. Cost-Benetif Ratio ( $\mathrm{R}$ ) by Class}

The results show that producers implementing low GAPs have a higher ratio than those who implement them strongly. These results are related to the variable costs that are highest for the class that strongly implements GAPs because of the increasing needs for increasingly scarce and expensive labour Marginal revenues do not compensate for the marginal costs induced by the adoption of GAPs. Producers who implement GAPs are less financially efficient (get rich less quickly) than those who implement them less. This paradoxical result reinforces the position of small-scale farmers implementing GAPs less, and rightly justifies the fact that the cashew economy cannot flourish. The results also show that small growers who implement GAPs less tend to be good managers These results reflect the fact that the higher the farm size in hectares of planted area, the less efficient the management of the farm, especially as farms operate in a difficult environment (climate, lack of proven technological progress, lack of funding, difficult access to roads, poor supervision, scarcity of salaried workforce, etc.). These results also reflect the competing objectives of the coaching organisation that pursues farm capitalization and of a destitute farm manager or producer who wants to maximize his profit. Productivity is a simple-looking indicator that measures the relationship between production and the factors required to achieve it. It is the primary indicator of the farmer's or farm manager's dashboard. For a destitute producer, local agricultural productivity is one of the drivers of economic growth; and the analysis of agricultural performance helps identify priorities to be defined in terms of agricultural strategies, accompanying measures, and support required. This leads them to be more rational in the use of production factors.

\section{Conclusion}

The objective of our study was to analyze the profitability of cashew farms in Côte d'Ivoire. This led us to ascertain whether the implementation of GAPs has an impact on performance and income. To do this, we started by characterizing farms using descriptive statistics. Then, we analyzed good agricultural practices by region and categorized producers by classes using the scoring method. And, we analyzed the financial profitability by region and by class with the budgeting method. The characterization of cashew farms showned that they were very mature with an average age of 27 years and low yields $(361 \mathrm{~kg} / \mathrm{ha})$. They were grown by direct seeding (94\%) over average areas of 5.34 ha with less than $10 \mathrm{~m}$ spacing between plants. The farms were sometimes associated with crops such as maize, peanuts, yam or cassava, but were mostly pure orchards.

The characterization of producers showed that cashew farms, most of which are inherited, are mainly the business of married men aged 46 on average and largely uneducated. Very few belong to cooperatives, and most have not received any agricultural advice (34\%). They have 15 dependents on average and have an average experience of 16 years. The analysis of good agricultural practices has shown that the producers, in creating and maintaining their farms, moderately $(54.7 \%)$ adhere to good agricultural practices popularized by the Cotton and Cashew Board through the ANADER staff. However, some practices such as overgrafting, coppicing, use of fertilizers or even strings for fruit separation, remain almost non-existent in producers' habits. In addition, 3 classes of producers have been highlighted: those who implement GAPs weakly, moderately, and strongly. The results showed that the implementation of GAPs had a positive impact on yield. However, when areas are too large, yields become low. Moreover, the analysis of financial profitability was made by region and by class. It showed that cashew generated a per hectare farming income 
of $157 \mathrm{CFA} F$ and a minimum production cost of $120 \mathrm{CFA}$ $\mathrm{F} / \mathrm{ha}$ as well as a cost-benefit ratio of 3.13 not taking into account labour. This testifies to the low financial profitability of cashew farming.

In terms of classes, our results show that the implementation of GAPs has a positive impact on farming income. However, the class analysis revealed that the strongest class producers have the highest cost of production and are the least financially profitable compared to those who implement GAPs less. This can be explained by the cost difference between the two classes.

Our results reflect the fact that the higher the farm size in hectares of planted area, the less efficient the management of the farm, especially as farms operate in an adverse environment (climate, lack of proven technological progress, lack of funding, difficult access to roads, poor supervision, etc.).

Our results also reflect the competing objectives of the coaching organisation that pursues farm capitalization and of a destitute farm manager or producer who wants to maximize his profit. Productivity is a simple-looking indicator that measures the relationship between production and the factors required to achieve it. It is the primary indicator of the farmer's or farm manager's dashboard. For a destitute producer, local agricultural productivity is one of the drivers of economic growth; and the analysis of agricultural performance helps identify priorities to be defined in terms of agricultural strategies, accompanying measures, and support required. This leads them to be more rational in the use of production factors.

In the light of the foregoing, we recommend that the coaching organisations should, based on this study, develop a base of financially profitable farms in order to guide their support for cashew farmers.

\section{References}

[1] Deloitte Côte d'Ivoire (2017), «Etude relative à la compétitivité du secteur de la transformation de l'anacarde en Côte d'Ivoire».

[2] Dandjinou B. (2016), Global Competitiveness: the Real Issues and How to Adress It - 20 September 2016.

[3] Chiapo A. (2018), «Déterminants de l'adoption des bonnes pratiques agricoles par les producteurs d'anacardes en Côte d'Ivoire».

[4] Ouattara G. M. (2017), «Les déterminants de l'adoption de certaines bonnes pratiques culturales avant récolte de la noix de cajou en Côte d'Ivoire», iosr journal of economics and finance (iosr-jef).

[5] Eddy B (2017), «Evaluation de la rentabilité économique et financière des exploitations d'anacardiers en Côte d'Ivoire», revue internationale de gestion et d'économie série b - économie / issue 3 - volume 2 - December 2017 / pp. 127-154.

[6] Paraïso A. A., Sossou A. C. G., Yegbemey R. N. et Biaou G. (2010), «Analyse de la rentabilité de la production du fonio (digitaria exilis s.) dans la commune de boukombé au Benin, j. Rech. Sci. Univ. Lomé (togo)», série a, 13 (1): pp. 27-37.

[7] National Institute of Statistics, (2017), «Etude économique et financière des entreprises en 201515 ème Edition» Yaoudé, Cameroun P22.

[8] Caroline K. P. Séhouéto et al (2015), «Évaluation technico-économique de la production de plants de teck (Tectona grandis L. f.) dans les pépinières villageoises au Sud-Bénin» Publication, Biotechnol. Agronon. Soc. Environ., 201519 (1); P32-41.

[9] Agba 1. \& Odoun-Ifa A. A. (2002)., «Analyse de la rentabilité économique de la production du coton dans quelques systèmes d'exploitation du Bénin».

[10] Paraïso A., Yabi A. J., Sossou A., Zoumarou-Wallis N. et Yegbemey R. N. (2011), «Rentabilité économique et financière de la production cotonnière à Ouaké au nord-ouest du Bénin», annales des sciences agronomiques 16 (1): pp 91-105.

[11] Assiri A. A., Kacou E. A., Assi F. A., Ekra K. S., Dji K. F., Couloud J. Y. et Yapo A. R. (2012), «Rentabilité économique des techniques de réhabilitation et de replantation des vieux vergers de cacaoyers (théobroma cacao 1.) En Côte d'Ivoire», journal of animal \& plant sciences, 2012 [online]. Vol. 14, issue 2: pp. 1939-1951. Publication date: 30/6/2012, ISSN $2071-7024$.

[12] Ayena M. \& Yabi A. J. (2013), «Typologie et rentabilité économique des exploitations agricoles participant au conseil à l'exploitation familiale», p18.

[13] Some L. F. M. C (2014)., «Analyse socio-économique des systèmes de production d'anacarde au Burkina Faso: cas des régions des cascades et des hauts-bassins», mémoire de fin de cycle en vue de l'obtention du diplôme d'ingénieur du développement rural, master option: sociologie et économie rurale; p66.

[14] Asala S. W. 1 * and Ebukiba E. S. 2, (2016), «Profitability of yam production in Southern Guinea Savanna zone of Nigeria», Net Journal of Agricultural Science Vol. 4 (1), pp. 9-14.

[15] Silué N. Z., Dao D., Kouamé V. H. K., Koné M. (2019), «Analyse de la rentabilité économique des systemes de production à base d'igname: cas des sites de Leo et Midebdo au Burkina Faso», Agronomie Africaine 31 (1): 1-14.

[16] Hafdhi F. E. (2016), «Comparaison de la performance financière d'une coopérative et d'une entreprise privée sur le secteur laitier en France», Mémoire de fin d'étude 2016, Ingénieur Agronome spécialité, Agromanager, p71.

[17] PSAC (2017), «Elaboration de la situation de référence du psac filière anacarde».

[18] Youan Bi T. B. A (2018). «Etude sur la rentabilité financière et économique de la culture d'anacarde en Côte d'Ivoire». 